\title{
Singulatives in Modern Celtic AND Slavic Languages: EVIDENCE FROM WELSH AND SORBIAN
}

\author{
SABINE ASMUS, EDUARD WERNER
}

\section{Introduction}

The existence of a singulative, i.e. a marked secondary singular inflection, is cross-linguistically relatively widespread and a number of linguistic strategies are commonly employed to express it (cf. the Bantu language Swahili, Insular Celtic, or Slavic). While various studies have addressed the singulative in nonIndo-European languages (e.g. Mous 1983: 63-72, see also Hewitt 2009: feature 35) or discuss them adequately in grammar books (e.g. Fallon 2006: 115 for the Cushitic Blin language, Raz 1983: 15-16 for the Semitic Tigre language), little work has been done on the singulative in any living IndoEuropean (IE) ${ }^{1}$ language. ${ }^{2}$ This is unfortunate, because in the modern p-Celtic languages the use of diminutive formants ${ }^{3}$ in order to form a secondary singular, i.e. a singulative, is quite productive, in particular in Welsh (Heinz 2003: 331-47, 2008: 111-27, 2009), Breton (Irslinger 2009) and Cornish (Brown 2001: 38). However, such formations do not form a central feature of the current q-Celtic languages and it remains unclear to what extent they ever did. Scottish Gaelic ${ }^{4}$ still has a few in use, e.g. falt 'hair' (head full of hair) fuiltean, 'a single/strand of hair', gaosaid 'a coat(ing) of hair' - gaosaidean 'a single/strand of hair' (cf. Welsh gwallt/blew), cuileag 'flies' - cuileagan 'a fly'. Examples for Irish ${ }^{5}$ are of archaic nature and rather isolated, e.g. folt 'hair' - foiltne 'a single/strand of hair', grán 'corn' - gráinne 'grain of corn',

\footnotetext{
${ }^{1}$ The same holds true for Standard Average European (SAE) languages. However, the Slavic languages do not belong to their core inventory and the Celtic languages are seen as either peripheral in that group (Whorf 1956: 13) or not belonging to it at all (Haspelmath 1998: 273 and 2001: 1505).

${ }^{2}$ One example of research carried out in this regard is Cuzzolin (1998). However, unfortunately, major cross-linguistic research, e.g. WALS (Dryer, Haspelmath 2013), does not address this category.

${ }^{3}$ For the definition of diminutives, on which this study is based, and the identification of Welsh ones, see Heinz (2009). A different approach is taken by Jurafsky (1996: 536).

${ }^{4}$ We would like to thank Caoimhín Ó Donnaile, a native speaker and lexicographer from Sabhal Mòr Ostaig, Scotland, for his comments on Scottish Gaelic singulatives and the examples provided.

${ }^{5}$ We would like to take the opportunity to thank our colleague Cormac Anderson for his comments in respect to Irish and the non-IE context as well as his suggestions for relevant literature.
} 
(ruain 'hair') - ruainne 'a single hair/little piece/fibre/thread' (Pedersen 1913: 57-58), lúaith 'ashes' - lúaithne 'cinder'. ${ }^{6}$

Looking at this feature cross-linguistically, it is obvious that even the more specific feminine diminutive-singulative forms a central category shared by some IE and non-Indo-European languages. It can be found in Breton and Cornish, but also in some Cushitic languages, Arabic, the Algic language Ojibwe and the Gur language Dagaare (Mathieu 2012: 195). Although it is widely recognised that the Celtic languages share properties of their structures with languages outside the IE-language context, the question of how these features developed has generated heated debates (see e.g. Isaac 2007, 2009). Consequently, the failure to explain such features as the result of language contact or as derived from a known substratum led individual scholars to partly disregard the existence of these features altogether or to develop possible explanations strictly within the IE context. An attempt in this vein was made by Irslinger (2009) with regard to singulatives, suggesting their emergence from language contact with Latin. Her argument is discussed further below and challenged there.

Through examination of evidence from Slavic languages, in particular Sorbian, a possible development of the singulative in both p-Celtic and Slavic is proposed below. Although not as productive as in the p-Celtic languages, clear traces of similar formations of the singulative can still be discerned in particular in Upper and Lower Sorbian and also survive in other Slavic languages. In addition, such a derivation pattern or the singulative is suggested for Old Greek below and it is suggested that singulatives were much more common in proto-IE. However, it is not claimed that this approach explains all diminutive or singularisation processes in the languages under discussion.

\section{The Welsh system}

As first outlined comprehensively in Heinz (2003: 335ff.), the Welsh noun exhibits four categories of number inflection. These are:

(a) nouns which exhibit plural inflection following the common singularplural opposition, e.g. cadair - cadeiriau 'chair - chairs'.

(b) nouns whose stems have plural meaning (often confused with plural nouns - see (d) below). Here a secondary singular inflection is used to single out individuals or realia (individuatives) as in mefus (coll.) 'strawberries' mefusen '(one) strawberry'; cf. Cornish sevi 'strawberries' - sevienn '(one) strawberry', Breton sivi 'strawberries' - sivienn '(one) strawberry'. The singulative is the marked form of a collective noun (cf. Strachan 1908, King 1993; see Breton dictionaries). As this category has been largely ignored in

${ }^{6}$ De Bhaldraithe (1978: 208) maintains that fúinín, fuinín represent foichnelfóichne, a singulative based on $\operatorname{fochan}(n)$. See also Thurneysen below. 
grammatical descriptions of Welsh, it is consequently confused with word formation patterns in most dictionaries and/or not properly featured at all, instead largely being made to conform to the morphology of the English noun system (for details, see Heinz 2003: 331-49, 2008: 111-27).

Nouns of this category seem to be strongly semantically motivated and tend to refer to collections of mini-realia, animate or inanimate, that would hardly appear or survive or have an effect as a singular entity, e.g. vegetables, fruits, corn, trees, livestock, weather phenomena (e.g. mellt 'lightening'), tools or substances. ${ }^{7}$ The last-mentioned category is of particular interest, because here the singulative tends to serve the function of fragmentation, which is further explained below (see (c)), a fact not mentioned by Irslinger (2009) at all.

(c) nouns with no plural form, i.e. singularia tantum. This group consists in particular of abstracta, but also nouns which denote substances, e.g. caws 'cheese' - cosyn 'a piece of cheese'. If these take a diminutive then the derivative expresses fragmentation and serves the function of semantic specification rather than that of number inflection, e.g. $g w y d r=$ substance + $y n=$ fragmentation (singularia tantum, masc.) 'piece of glass' + plural = gwydrynnod 'cullet'.

Where a substance noun has the same form as an unmarked one, as seen in $g w y d r$ '(a) glass', the same suffix is confined to its diminutive and then acts as a word formation device, e.g. $g w y d r$ (masc.; tool) $+-y n=$ diminutive (masc., pl. - au), 'little glass/glass of...'

These differences between the grammatical functions of the suffix $-y n /-e n$ and its role in word formation have - as pointed out by Heinz (2003: 331-47, 2008: 111-27, 2009: 193-6) - not yet been investigated in any detail, though a further study into this topic exceeds the scope of this paper. So far it can be safely said that diminutive meaning in Welsh seems to strongly support the concept of fragmentation with singularia tantum and that of singularity with collective nouns.

This rule may not exist in Breton or Cornish. Looking at Breton erc'henn 'snow-covered place' in comparison to the singularisation of Cornish ergh 'snow' - erghenn 'snow-flake', the concepts of concretion ${ }^{8}$ and confinement become relevant. Based on the Welsh model as explained above, Breton imagines 'snow' as a substance using a diminutive to express the idea of confinement,

\footnotetext{
${ }^{7}$ For a more exhaustive list, see Irslinger (2009), Burgschmidt $(1984,1990)$. However, none of the categorisations proposed are truly satisfactory and further research in this regard is required.

${ }^{8}$ Comparable isolated and differently distributed forms can also be found in German, e.g. Kaffee 'coffee' - Käffchen 'cup/pot of coffee', Staub 'dust' - Stäubchen 'speck of dust', Roggen 'rye' Röggelchen 'rye roll'. Indeed Borgdorff (2008: 69-70) identifies singularity as a feature of welldeveloped diminutivisation in German for $0.4 \%$ of its diminutive formations. There are also traces of such diminutivisation in Dutch, e.g. snoep 'sweets, candy' - snoepje 'sweet, piece of candy', indicating that diminutive formations may in many languages be considered acceptable for '(various aspects of) confinement'.
} 
whereas Cornish imagines it as a mass noun/collection of entities using a singulative - employing the same diminutive - to single out one little entity. However, these semantic subtleties and their link to morphology have not yet been sufficiently examined.

The fact that Welsh diminutives employed as a number inflection device for collective nouns ${ }^{9}$ used to be or can be further inflected (see $g w y d r$ above) ${ }^{10}$ shows clearly that the various uses of -yn/-en are more strongly anchored in this language system than it might appear at first glance and, therefore, merit further analysis.

(d) The last category is formed by nouns which have no singular form, i.e. they form the group of pluralia tantum, e.g. lloffion 'gleanings'. They may need a partitive for quantification as in llawer o newyddion 'a lot of news', but are not relevant for the purpose of this paper.

\section{Singulatives in Slavic languages}

As the dichotomy collective-singulative has no parallel in the metalanguage and former language of academic discourse, Latin, it is widely ignored in descriptions of the Slavic languages too. As mentioned above, the concept of the singulative appears to be little known in Slavic languages and, therefore, needs to be given particular attention in the following.

\subsection{Russian ${ }^{11}$}

It is safe to say that for modern Russian there are only isolated and marginalised forms of the singulative. Its formation, however, resembles that of the p-Celtic languages (and others as shown above), i.e. it makes use of diminutive suffixation, with the help of three suffixes used in Russian:

(a) the suffix - $\kappa$ - (+ a-stem ending): шоколад 'chocolate' - шоколадка (fem.) '(a) piece of chocolate'

Remnants of linguistic properties are often also preserved in dialectal forms or are confined to specific semantics and used for limited (or uncommon) denotations of certain phenomena. This is predominantly the case with fruits/vegetables in some Slavic languages, e.g. Polish and Russian. The latter features for instance in морковь 'carrots' - морковка 'one carrot' (see

\footnotetext{
${ }^{9}$ This view is confirmed by Mathieu (2012: 195), though his statement on the changing genus in Welsh is incorrect.

${ }^{10}$ This also holds true for Cornish and Breton (Mathieu 2012: 196-197). Mathieu (ibid. 197) calls this property of British a rather general phenomenon of "higher projection".

${ }_{11}$ We would like to take the opportunity and thank Professor Molchanova from the University of Sczcecin/Poland for her extensive comments on this section and proposals for further reading.
} 
also Polish (coll. + dim.) and Welsh moron - moronen), peduc 'radish' редиска 'one radish' (see Polish below and Welsh rhuddygl-rhuddyglen). ${ }^{12}$

The still productive function and potential use of singulatives denoting vegetables and fruits is well reflected in the formation of personal names in the Russian translation of Il romanzo di Cipollino by Gianni Rodari, which is commented on as follows:

Russian marginally uses diminutive morphology [...] for the so-called singulative function [...] with the diminutive suffix $-\mathrm{k}[\ldots]$ Note that the diminutive used for the singulative function also imposes the feminine gender on the noun stem that is masculine by itself. ${ }^{13}$ Since the characters of the Cipollino story are individuals rather than substances, the diminutive/ singulative form is used in the Russian where available: [...] Zemljanichka ('Strawberry') [...] Perhaps, the one character whose name illustrates best both the challenges that the Russian translator faced and his genius is the detective Mr. Carrot. The Italian word for 'carrot' - carota - is feminine, but the character is conceived as a male (recall that in 1951, when the book was first published, being a detective was still "an unsuitable job for a woman"). In Russian there are two words for 'carrot': morkov' and morkovka. The former is not very appropriate as a name for our character because it is both feminine and a mass noun. The latter is only marginally better (because it's a count noun): it is still feminine but the diminutive/singulative suffix $-k$ deprives it of the social weight needed for a real, serious detective [...] (Pereltsvaig 2011).

(b) Another language domain in which declining linguistic features are likely to be preserved are personal names. Some of these are old singulatives derived from collectives denoting social and territorial entities by the use of the (masculine) diminutive -in, ${ }^{14}$ as demonstrated in Korpela's research on medieval Russian chronicles, where he writes:

The collective words čjud', ${ }^{15}$ vod', sum', ves' and jem' look like the noun Rus'. At first glance, they seem to refer to realms or administrative or cultural units and not just to people living somewhere. On the other hand, using these expressions the Novgorodians $\mathrm{i}[\mathrm{m}]$ plied first of all a group of people because the texts use verbs in plural forms (Korpela 2008: 43).

And he continues:

\footnotetext{
${ }^{12}$ The former collective-singulative opposition is breaking down but maintained in so far as peduc is still uncountable and functions as a generic term.

${ }^{13}$ This is not necessarily true as can be seen in the following discussion.

14 This suffix is interesting in that it can also serve the function of augmentation, e.g. in рыбина 'big fish' (see Wilske 1978: 175, 178), as can the Welsh diminutive -yn/-en (see Heinz 2009).

${ }^{15}$ This transliteration is different from the more popular one used in the previous quotation, but common in academic discourse, cf. http://en.wikipedia.org/wiki/ Romanization_of_Russian.
} 
According to I.P. Shaskol'skij there were concepts Rus' - rusin, $\left[{ }^{16}\right]$ Čud' čudin $\left[{ }^{17}\right]$ and Jem'- jemin. The first is a collective concept for the people while the second an individual word for a member of that people. The expression rusin is recorded [...], but the words čudin and jemin are only known as individual names. Semen Jemin was tysjackij (kommander of emergency volunteer corps) of Novgorod in 1219 [...] and Čudin Mikula a Kievan Boyar in the late- $11^{\text {th }}$ century [...] (ibid.: 51 ).

More examples come from the $12^{\text {th }}$ and $13^{\text {th }}$ centuries and are given in the following quotatation:

Отец Прокши Водинича носил прозвище либо Вода [...], либо водинъ 'вожанин' (от водb, ср. чюдинъ от чюдь, лопинъ от лопь, либинъ от либь, русинъ от русь, литвинъ от литва. (Zaliznjak 2004: 509).

The father of Prokša Vodinič had the nickname Voda ${ }^{18}$ or Vodin 'a member of the Vod' ethnos' (from Vod', cf. Lopin from Lop', Libin from Lib', Rusin' from Rus', Litvin' from Litva).

In all these cases, the word for the individual is derived from a collective noun indicating the name of a tribe or ethnos which has singular agreement with adjectives ${ }^{19}$ but plural agreement with the verb as can be seen in 'pridoša em' na vod"' 'and the Em' attacked [3. pl. aor.] the Vod' (Korpela 2008: 50). This syntax is similar to that found in the Slěpe dialect of Sorbian in the case of skót 'cattle', which inflects like a noun in the singular, but shows plural inflection with both adjectives and the verb (see 5.1.).

Furthermore the collective-singulative patterns explained here seem to be marginally intact elsewhere, for instance in славяне 'Slavs' славянин/славянка ${ }^{20}$ 'one Slav(ic person) [masc./fem.]'. ${ }^{21}$ The same paradigm exists in Polish, i.e Stowianie - Stowianin, but is inaccurately described in academic literature. $^{22}$

There are also marginally productive feminine singulative formations ending in -ина, e.g. жемчуг 'pearls' - жемчужина 'a pearl', горох 'peas' горошина 'one pea' (cf. Welsh pys - pysen), картофель 'potato' -

\footnotetext{
${ }^{16}$ For further details as to its origin, see also (Vasmer 1958: 551).

${ }^{17}$ This formation seems to have become archaic at an early stage, as not even the name чудин is popular anymore. For further details as to its origin, see also (Vasmer 1958: 378).

${ }^{18}$ This lexeme must not be confused with the word for English 'water'.

${ }^{19}$ For agreement in Breton and Cornish, see Jørgensen 2011.

${ }^{20}$ Here another feminine diminutive suffix is used, i.e. -инк-.

${ }^{21}$ Such formations, where natural rather than grammatical gender may be used, can also be found in Welsh (see below).

${ }^{22}$ The grammatical descriptions given in modern grammar books explain this formation the wrong way around by saying that the "singulative -in suffix is dropped in the plural" (Swan 2002: 80). Similar explanations can be found in modern Welsh grammar or other reference books when trying to explain how the Welsh plural is formed (see Heinz 2003: 63), which distort a perfectly appropriate system to make it conform to English morphology.
} 
картофелина 'a potato' (cf. Welsh tatws - taten), as Cuzzolin (1998: 128) points out. However, these are clearly of more recent date because, firstly, they occur in relatively new (loan-)words like картофелина or жемчужина. ${ }^{23}$ Secondly, from a cross-Slavic point of view горошина must be newer than Upper Sorbian (Uso) hróšo, which has no synchronic motivation. Therefore, while Cuzzolin's work has the merit of pointing out that singulatives are by no means unknown in the Slavic languages, the formations investigated by him can hardly be genetically related to the p-Celtic singulatives we are interested in here. (c) Wilske (1978: 184) also mentions the diminutive suffix $-u н \kappa-+a$-stem ending and the following examples солома 'straw' - соломинка 'a straw' (cf. Welsh gwellt - gwelltyn), пьль 'dust' - пьлинка 'speck of dust' (cf. Welsh $u l w-u l w y n$, or marwor 'ash' - marworyn 'speck of ash').

\subsection{Polish}

There are some remnants of diminutive-singulative formations surviving from older stages of Polish, e.g.

- Po marchew 'carrots' - marchewka 'one carrot' (see Russian and Welsh in 3.1.)

- Po rzodkiew 'radishes' (former coll.) + diminutive => rzodkiewka 'one carrot';

Rzodkiew now has a specialist/dialectal meaning and rzodkiewka a new plural, i.e. rzodkiewki. The former paradigm rzodkiew (coll.) - rzodkiewka (sing., see Russian and Welsh in 3.1.) consequently changed to rzodkiewka - rzodkiewki (sing. - pl.). ${ }^{24}$

\subsection{Sorbian}

There are also isolated forms of the type described thus far in Sorbian, e.g. Upper Sorbian sněh 'snow'- sněženka 'snowflake' (cf. Cornish erghennin mentioned in section $2^{25}$ ), trawa 'grass' - trawicka 'blade of grass'. However, diminutivisation does also seem to serve other functions in Sorbian, i.e. that of specifying in the broadest sense, here making something concrete and definite,

\footnotetext{
${ }^{23}$ The latter can only have been entered Old Russian after the loss of the front nasal vowel; otherwise we would expect *жячужина.

${ }^{24}$ As indicated before, such shifts of paradigms towards those more familiar linguistic structures as known in the dominant IE contact languages can also be observed in Welsh, promoted, of course, by the dominant English-language orientated descriptions of the Welsh language (Heinz 2003: 473-92) in a socio-linguistic situation where learners outnumber native speakers (Heinz 2003: 240-67).

${ }^{25}$ Welsh conceptualises 'little entities of snow' in a different way, i.e. as feathers. These, however, are singled out, as in Cornish by the diminutive-singulative as can be seen in plu eira 'feathers of snow' - pluen eira. Consequently the same semantic idea of 'something normally coming en masse', which would only be looked at in detail for specific purposes, is conveyed.
} 
i.e. defining an entity out of a more abstract, seemingly un-restricted concept like an action:

- zdźélenje 'the messaging' - zdźélenka 'a message'

- namakanje 'act of finding' - namakanka 'something that is found'

\section{Preliminary conclusions}

Diminutive-singulatives form a central category in Welsh (but also Breton and Cornish, i.e. the p-Celtic/British languages). It does, however, also feature regularly in reduced form in other IE languages, at least in the Slavic ones. As indicated before, diminutive-singulatives are very marginal in Scottish Gaelic, the closest Goidelic contact language of Welsh, ${ }^{26}$ and unproductive in Irish (some remnants in isolated forms).

When used in Slavic, the diminutive-singulatives seem to be generally found in similar semantic groups as in Welsh, e.g. with plants and their fruits, for instance vegetables or weather phenomena. However, the evidence from Sorbian hints at a potentially even broader use of the concept of diminutivisation.

In addition, as indicated before, cross-linguistically diminutivesingulatives are frequently linked to feminine gender, as seen in p-Celtic Breton and Cornish. A focus on the feminine gender is also apparent in some Cushitic languages, Arabic, Ojibwe, and Dagaare, but not consistent in the Slavic languages. In Russian and Upper Sorbian, for instance, the biological gender may be kept. This is not true for Welsh and the older stages of Russian or the Irish remnants. Indeed, in Welsh there exists a highly productive masculine form for the diminutive, i.e. $-y n$. It is suggested that the feminine -en is the original suffix and thus features early in many place-names in Wales, e.g. Glynarthen, Cennen (Kennen Riveret), Llandeiniolen. ${ }^{27}$ Wyn Owen and Morgan (2007: 58) maintain that it derives from Brit. *-innā, OW -enn, ModW -en.

Thurneysen identifies several diminutives for Old Irish, amongst others án and -én. Whereas he links the first one to British -óg, he places -én and the later -ín in one and the same entry without convincing explanations as to their relation (Thurneysen 1909: $169^{28}$ and 1946: 174). Although there are close linguistic links between the early stages of Irish and British or early Welsh, their interrelations and mutual influences are in no way clear for the development of

\footnotetext{
${ }^{26}$ This statement is made considering that there is no clear evidence as to which language group the former contact language Pictish should be allocated.

${ }^{27}$ According to the place name evidence -en could alternate with -yn, e.g. Landeynyolen 1284, Llandimolyn 1384, Llandynyollyn 1436 (cf. also the alternation of e/y between the p-Celtic languages).

${ }^{28}$ The English and German versions of Thurneysens's grammar differ in their explanations concerning the diminutives, which indicates that the development of the diminutive formants in Old Irish remains unclear.
} 
the diminutive suffixes. All that can be said is that the Welsh diminutive -en can alternate with -yn and also with -an (cf. Welsh jobyn, joban, joben 'a little job', llyfran 'little book'- llyfryn 'booklet'). ${ }^{29}$

In addition, it remains unclear how these diminutives evolved into singulatives in p-Celtic. As indicated above, Irslinger (2009) assumes that this happened during a phase of intensified resuffixation induced by a similar process in medieval Latin. However, Irslinger fails to explain how this should have given rise to singulatives in the p-Celtic languages as she fails to show both the semantic and formal parallels. Indeed, on that premise, such developments should also have been expected for Irish, which at an early stage came in contact with non-native and native Latin learning, or for Old English. Both languages had very intensive contact with Latin in the early Middle Ages. But whereas there are diminutive-singulatives in Old Irish and a limited range of formations in its later offspring, Scottish Gaelic, this is not the case in English.

\section{In search of potential shared linguistic features and/or developments between the Celtic and Slavic languages}

Given that the concept of diminutive-singulatives has survived productively ${ }^{30}$ better in marginalised languages in Europe, the question arises as to whether there are any possible genetic links between some of the languages that make use of that category. Therefore another, closer look at the Slavic languages is presented below, which reveals more frequent collective-singulative oppositions, though seemingly not linked to diminutive-singulatives.

\subsection{Singulatives formed by $-n t$ stems in Slavic languages}

In order to derive singulatives from collectives, - $n t$ stems could be used in the Slavic languages, as can be seen, for instance, in Russian дитя 'a child', USo dźéćo, Polish (Po) dziecię (PS1 *dětb coll. 'children', see Vasmer 1958: 353). Although it was recognised earlier by scholars that $-n t$ stems do not always denote young animals or people, it was seen as a newer semantic shift, as is explained in the following quotation from Dobrzyński (1974: 50):

Wszystkie te rzeczowniki [...] oznaczaja dzieci zwierząt lub ludzi; jeżele dziś niektóre, jak bydlę, zwierzę, ksiązę, sa nazwami istot dorostych, musi to być wynikiem wpływów późniejszych, których jednak bliżej określić nie umiemy.

All these nouns denote the offspring of animals or people; if nowadays some of them, like bydle '(a) specimen of cattle', zwierze '(an) animal', ksiąze 'prince', refer to adult creatures, then this must be due to later influence, which we cannot define in more detail.

\footnotetext{
${ }^{29}$-an seems to be clearly diminutival and tends to be less lexicalised (cf. Heinz 2009: 190).

${ }^{30}$ The productivity refers to Sorbian and the p-Celtic languages.
} 
However, Dobrzyński (ibid.: 50) eventually came to see these formations as singulatives saying "pewna ilość przykładów, w których formant -e nie petni ani funkcji deminutywnej, ani emfatycznej, lecz singulatywna," "[there is] a certain number of examples, in which the formant -e does not fulfill the diminutive or emphatic function, but a singulative one'. But although he recognised that these singulatives were old (stating "te które sq, występuja bardzo często i to od czasów najdawniejszych" "those we find occur very frequently since the earliest times' (ibid.)), he still thought them to be newer than diminutives ("pierwotna, wyraźnie deminutywna, a zwtaszcza hipokorystyczna funkcija tego formantu została częściowo zatarta," "the original, strongly diminutive and basically hypocoristic function was often corrupted' (ibid.)).

The collective-singular opposition seems to be still in reduced use, as seen in the following examples:

- Po dobytek 'cattle' - dobytcze, bydto 'cattle' - bydlę '(a) specimen of cattle'

- USo skót 'cattle' - skoćo '(a) specimen of cattle'

- LSo zbóže (*zbožbje - o-stem) 'cattle' - zbóže (*zbože -nt stem) '(a) specimen of cattle'

- USo hroch 'peas' - hróšo 'one pea'

- USo zorno 'crops, cereals' - zornjo 'grain of seed'

- USo smudy 'gunpowder' - smudźo 'powder crumb'

- Po pótkorcze 'half a bushel' (pół korca), jednokole 'half a cart' (jedne koło)

- Schleife dialect (Slěpe) skót 'cattle'-skóće '(a) specimen of cattle'

In the last example, the collective noun is not only maintained semantically but also grammatically, as can be seen in the non-agreement between noun (sing.) and predicate (3. pl.) in the following expression: naše skót su južont jědli 'our (nom. pl.) cattle (nom. sing.) [copula (3. pl.)] already eaten (1. pl.)'; see also wót našych skótu 'of our (gen. pl.) cattle (gen. sing.)'.

\subsection{Changing paradigms}

USo has swinjo 'pig' (PSl *svinz coll. 'swine'), a lexeme exhibiting an -nt stem insertion, which was originally used to express a singulative, as in plóćo 'one birch boletus', or kurjo 'one chanterelle', also runjo 'one of a pair ${ }^{32}$ (cf. Polish bliźnię 'twin' and prućo 'rod' vs. Old Czech prout 'rods' (for basketry), or Russian ymя 'a duckling'). As seen with the diminutive-singulatives given above for Polish, but also Russian, in which the original collective base word now often constitutes a normal masculine noun in the singular, there is a trend

\footnotetext{
${ }^{31}$ We would like to take this opportunity to thank our colleague Hync Rychtar for providing this material from his private database of the dialect of Schleife/Slěpe.

${ }^{32}$ For further details on $-n t$ formations in Sorbian, see Wornar (forthcoming).
} 
for these paradigms to give way to normal, i.e. IE, singular-plural ones. Occasionally the former collective can still be recognized semantically as a generic term and/or a non-countable noun.

\subsection{Semantic shift and productivity}

Apart from adapting singulatives to the commonly known singular-plural number system in the IE languages, the $-n t$ stems developed differently in Western Slavonic languages and underwent a semantic shift, thus remaining synchronically productive for the derivation of denotations for young animals as can be seen in, for example, USo law 'lion' - lawjo 'young lion', krokodil krokodilo, mjedwjedź 'bear' - mjedwjedźo 'young bear'; though, as illustrated in examples above, Sorbian has to some extent also preserved the original semantics of the singulative.

In Macedonian - $n t$ stems are currently used for the derivation of diminutives, as can be seen in мост 'bridge' - мосте 'little bridge', книга 'book' - книже 'little book'. Most productive is -че $(\mathrm{k}+-n t)$ : парк 'park' паркче 'little park', камен 'stone' - каменче 'little stone'.

\subsection{Parallels with non-Slavic examples}

In Attic $\delta o ́ \rho v$, gen. $\delta o \rho o ́ \varsigma$ 'wood' and later $\delta o ́ \rho \alpha \tau o \varsigma$ can be found (Frisk 1973: 411). However, we suggest that $\delta$ ó $\alpha \tau o \varsigma$ (*dorvntos 'wood/piece of wood') is originally the genitive of $\delta o \rho \alpha \dot{\alpha}(* d o r v n t$ 'roof beam'). Hence, the original paradigm and semantics would have been $\delta o \rho \alpha ́$ - $\delta$ ó $\alpha \tau o \varsigma$ 'a piece of (machined) wood' as opposed to $\delta o ́ \rho v$ 'wood (mass noun, nom. sing.)' $-\delta o \rho o ́ \varsigma$ 'wood (gen. sing.)'. After the loss of the singulative as a productive category in Old Greek, this semantic opposition was also lost. In Classical Greek, the paradigm was re-arranged and the genitive of the former singulative was assigned to the nominative of the mass noun. The old opposition $\delta$ ó $\rho v$ (mass noun) - $\delta o \rho \alpha$ ' 'a piece of (machined) wood' corresponds phonologically and semantically to Welsh derw 'oak wood' vs. derwen 'oak tree' or Cashubian dřéwo 'wood' vs. dřéwa 'tree'. These two examples also display the same semantics; cf. also Cornish gweder (substance) - gwedrenn 'a piece of (machined) glass/drinking glass'.

Regarding the gender of these formations we would suggest that they were originally neuter as preserved in the Old Greek and various Slavic examples. In the p-Celtic languages, their gender changed due to the loss of the neuter gender before their emergence as individually recognisable languages. The evidence from languages which feature singulatives as a central category, ${ }^{33}$ in particular the non-IE languages (see introduction and chapter 4) and to a large extent also Slavic singulatives, such as USo sněženka,

\footnotetext{
${ }^{33}$ In German, where the singulative, as indicated above, is marginal, the diminutive forms neuter derivatives.
} 
would suggest the formation of feminine derivatives as seen in Cornish and Breton. In Welsh (Russian and Upper Sorbian), however, there are, as mentioned above, also masculine singulatives. Old Irish has gendermaintaining suffixes (Thurneysen 1909: 167, 1946: 173). Though masculine singulatives are, according to Irslinger (2009: 234), less frequent than feminine formations, they seem to feature quite prominently in modern Welsh, e.g. caws 'cheese' - cosyn 'a piece of cheese', blew '(body) hair/ fur' - blewyn 'a single hair/whisker' (see also examples above).

\subsection{Interpretation}

In light of the examples above, Szychta's interpretation (1967: 25) of Cashubian drèía as młode drzewo 'young tree', needs to be corrected and 'young' replaced by 'one' (though 'little' may be applicable as a secondary meaning). This interpretation is confirmed by evidence from proverbs, i.e. archaic linguistic expressions as found in Cashubian Jedno dřéẃa to ješ ńe je las 'One tree is not yet a forest' ('One swallow does not make a summer'), or Čim dale v las, tim ẃicè dřèwat, čim dale we wes, tim wicè zèvčat 'The further into the forest, the more trees [not 'saplings']'.

These findings also call into question Irslinger's argument that the British singulative developed from language contact between Latin and the British language, since neither such a formant nor semantic function was identified by her in Latin. This is a violation of the principle in historical linguistics of the unity of form and function of language units (see Szemerényi 1980: 6-7).

Returning to $-n t$ formations, they were apparently wide spread and most probably PIE (cf. Worner forthcoming). - $n t$ singulatives seem to disappear as a regular pattern in most IE language families with remnants preserved mostly in isolated or irregular forms. However, as shown above, in semantically and morphologically altered form, $-n t$ singulatives seem to have survived productively in (a) Sorbian (to denote mainly 'young animals') and (b) in Macedonian (to form diminutives proper). It also looks as if this pattern continued in some p-Celtic diminutive-singulative formations; here, however they are employed to express realia and phenomena in semantic fields as found within and outside the IE context (see chapter 2).

\section{Final conclusions}

As diminutivisation seems to be a universal concept (see Jurafsky 1996: 534-6), singularisation is also likely to be a wide spread concept, linked to basic realia of many cultures, like 'trees' in p-Celtic, Slavic, Tigre and Arabic, similarly 'dust', vegetables and fruits or 'hair' in Cushitic, Tigre, Arabic, Swahili and Insular Celtic. Concepts cross-linguistically preferred for singularisation can be roughly summarised as mini-realia, animate or inanimate, that would hardly come about or survive or have an effect as a singular entity, e.g. vegetables, fruits, corn, 
trees, livestock and weather phenomena. However, more cross-linguistic research on this category is needed to determine what the exact relationship between diminutivisation and singularisation is. Answers to the following questions should also be sought: (a) how are various concepts of confinement, i.e. singularisation, fragmentation or concretion are interrelated? (b) what morphological and/or semantic properties of the base noun ${ }^{34}$ (including links to counting systems; see Mathieu 2012: 197) are employed in order to express one or the other? (c) on what basis is a suffix is chosen when there is more than one available, as for instance in Welsh (see preliminary work by Heinz (2009: 18799) in its regard)?

Welsh evidence shows that according to the actual semantics and morphology of the base word, either diminutivisation or singularisation may be preferred, but, depending on their semantic range, both are possible with certain words, e.g. Welsh gwydr (see section 2). But changing semantics may have paved the way, though to different degrees (cf. differences between Welsh, Breton and Cornish as displayed above) for a merge of -nt-stem functions with diminutive suffixes in the languages under discussion. The conclusions drawn so far and the desiderata identified above tie in nicely with the results of Mathieu's research (2012: 196ff.) in relation to the singulative in Ojibwe. Mathieu writes that

The function of the singulative [thus] consists not only in turning abstract object types into identifiable objects, but also picking discrete entities out of undifferentiated mass. As pointed out by Acquaviva (2008: 254), the precise sense of the unit of measure readings varies with the word. This state of affairs is wide-spread in languages that allow the singulative and is exactly what we find in Ojibwe [...]

He consequently states "its importance in the grammar of many languages, including as I have shown in this chapter, Ojibwe, shows that the singulative deserves a central place in the theory of division" (ibid.).

Seeing the importance of singulatives it should be noted that ways of expressing the singulative-collective dichotomy are varied. Two seemingly distinct concepts were explored here: (a) the diminutive-singulative and (b) the derivation from old $-n t$ stems. It was suggested that there might be a genetic link between the British feminine diminutive-singulative -en(n) and PIE - nt stems preserved to some extent in Slavic and found in traces in Old Greek. There seems to be none, however, between the marginal Slavic diminutivesingulative $-k+a$ - and $-n t$ stems or others, like -in, -ina, -ink $+a$ and $-n t$ stems,

\footnotetext{
${ }^{34}$ This is another aspect completely ignored by Irslinger (2009) but briefly outlined in Heinz (2009).
} 
though the semantics of all of these are similar. Questions also remain as to the Welsh - yn suffix and those formations found in the q-Celtic languages.

Why the collective-singulative opposition remained particularly productive in the British languages remains equally uncertain as does the answer to the question why Breton and Cornish follow the cross-linguistic tendency for feminine diminutive derivatives used for singularisation.

Sabine Asmus (Szczecin University, Poland/ Leipzig University, Germany) Eduard Werner (Leipzig University, Germany)

\section{References}

Acquaviva, P., 2008, Lexical Plurals, Oxford: Oxford University Press.

Borgdorff, D. W., 2008, Zur Semantik der Diminutive in der gegenwärtigen Schriftsprache des Deutschen, GRIN Verlag.

Brown, W., 2001, A Grammar of Modern Cornish, Callington: Penwell Ltd.

Cuzzolin, P., 1998. 'Sul l'origine del singolativo in Celtico, con particolare riferimento al medio Gallese', Archivio Glottologico Italiano 83.2, 121-49.

de Bhaldraithe, T., 1978, 'Fúinín, fuinín', Éigse 17, 2, 208.

Dobzyński, W., 1974, Z badań nad rozwojem polskich deminutywów, I. Historyczny rozwój rzeczowników z formantem -e na tle stowiańskim [Research on the evolution of Polish diminutives, I. Historical evolution of nouns with the formant $-e$ in Slavic], Wrocław.

Dryer, M. S., Haspelmath, M., eds., 2013, The World Atlas of Language Structures Online, Leipzig: Max Planck Institute for Evolutionary Anthropology (available at http://wals.info accessed 10.06.2014).

Fallon, P.D., 2006, 'Consonant Mutation and Reduplication in Blin Singulars and Plurals', in: Mugane, J. et al., eds., Selected Proceedings of the $35^{\text {th }}$ Annual Conference on African Languages, Sommerville, MA: Cascadilla Proceedings Project, 114-24.

Frisk, H., 1973, Griechisches Etymologisches Wörterbuch, Heidelberg: Winter.

Haspelmath, M., 2001, 'The European Linguistic Area: Standard Average European', in: Haspelmath, M. et al., eds., Language Typology and Language Universals: An International Handbook. Volume 2, Berlin/New York: de Gruyter, 1492-510.

Haspelmath, M., 1998, 'How Young is Standard Average European?', Language Sciences 20:3, 271-87.

Heinz, S., 2003, Welsh Dictionaries in the Twentieth Century - a Critical Analysis, München: Lincom Europa. 
Heinz, S., 2008, 'Remarks on Selected Welsh Word Classes: Articles, Adverbs and Nouns', in: Bloch-Rozmej, A., ed., Issues in Celtic Linguistics. Lublin Studies in Celtic Languages. Volume 5, Lublin: Wydawnictwo KUL, 109-27.

Heinz, S., 2009, 'Diminutive Formations in Modern Welsh', in: BlochTrojnar, A., eds., Perspectives on Celtic Languages, Lublin Studies in Celtic Languages, Volume 6, 187-99.

Hewitt, S., 2009, 'The question of a Hamito-Semitic Substratum in Insular Celtic', Language and Linguistics Compass 3, 972-95.

Irslinger, B., 2009, 'Singulative and Kollektiv in den britannischen Sprachen', in: Hinrichs, U. et al., eds., Eurolinguistik. Entwicklungen und Perspektiven, Wiesbaden: Harrassowitz, 233-53.

Isaac, G., 2007, 'Celtic and Afro-Asiatic', in: Tristram, H.L.C., ed., The Celtic Languages in Contact. Papers from the Workshop within the Framework of the XIII International Congress of Celtic Studies, Bonn, 26-27 July 2007, Potsdam: Potsdam University Press, 25-80.

Isaac, G., 2009, 'Celtic and Afro-Asiatic: a Further Note on the Theory of Prehistoric Contact between them', in: Zimmer, S., ed., Kelten am Rhein. Akten des dreizehnten Internationalen Keltologenkongresses, 23. bis 27. Juli 2007 in Bonn. Zweiter Teil. Philologie. Sprachen und Literaturen, Mainz: Verlag Phillip von Zabern, 95-103.

Jørgensen, A.R., 2011, 'The Plural of bihan, byhan 'little, small' in Breton and Cornish', paper given at the meeting Indo-European Matters Even More! Copenhagen, University of Copenhagen, 12-14 October 2011 (available at http://rootsofeurope.ku.dk/kalender/arkiv_2011/indo-european_matters_even_ more /20111013-handout_anders_richardt_joergensen/, accessed 10.06.2014.

Jurafsky, D., 1996. 'Universal Tendencies in the Semantics of the Diminutive', Language 72, 533-78.

King, G., 1993, Modern Welsh: A Comprehensive Grammar, London: Routledge.

Korpela, J., 2008, 'North-Western "Others" in Medieval Russian Chronicles', Učenye zapiski Petrozavodskogo gosudarstvennogo universiteta 2 (93), 42-55. Mathieu, E., 2012, 'The Mass/Count Distinction in Ojibwe', in: Massam, D., ed., Mass across Languages, Oxford: Oxford University Press, 190-8.

Mous, M., 1983, A Grammar of Iraqw, Kuschitische Sprachstudien Bd. 9, Hamburg: Buske Verlag.

Owen, H.W., Morgan, R., 2007. Dictionary of the Place-names of Wales, Llandysul: Gomer.

Pedersen, H., 1913, Vergleichende Grammatik der keltischen Sprachen, Göttingen: Vandehock und Ruprecht.

Pereltsvaig, A., 2011, 'Fruit, vegetable, boy, girl...', http://languages oftheworld.info/translation/fruit-vegetable-boy-girl.html (accessed 10.06.2014). 
Raz, Sh., 1983, Tigre Grammar and Texts, Malibu: Undena Publications.

Stankiewicz, E., 1986, The Slavic Languages Unity in Diversity, Berlin/ New York: Mouton de Gruyter.

Strachan, J., 1908, An Introduction to Early Welsh, Manchester: At the University Press.

Swan, O., 2002, A Grammar of Contemporary Polish, Indiana: Bloomington.

Szemerényi, O. 1980, Einführung in die vergleichende Sprachwissenschaft, Darmstadt: Wissenschaftliche Buchgesellschaft

Szychta, B., 1967-1976, Stownik gwar kaszubskich na tle kultury ludowej [Dictionary of the Cashubian Dialects based on folklore], Wrocław/ Warszawa/ Kraków/ Gdańsk: Wydawnictwo polskiej akademii nauk.

Thurneysen, R., 1909, Handbuch des Alt-Irischen, Grammatik, Texte und Wörterbuch, Heidelberg: Carl Winter's Universitätsbuchhandlung.

Thurneysen, R. 1946, A Grammar of Old Irish, Dublin: The Dublin Institute for Advanced Studies.

Toner, G., et al., eds., eDIL 2013 - Royal Irish Academy's Dictionary of the Irish Language based mainly on Old and Middle Irish materials, revised electronic edition, Queen's University of Belfast (http://edil.qub.ac.uk/dictionary/search.php). (accessed 10.06.2014)

Vasmer, M., 1950-1958, Russisches etymologisches Wörterbuch, Heidelberg: Winter.

Whorf, B.L., 1956, Language, Thought, and Reality: Selected Writings of Benjamin Lee Whorf, Cambridge MA: MIT Press.

Wilske, L., 1978, Die russische Sprache der Gegenwart. Lexikologie, Leipzig: Verlag Enzyklopädie.

Wornar, E., forthcoming, 'K nt-zdónkam w serbšćinje' [On the nt-stems in Sorbian], Lětopis, Bautzen: Domowina publisher.

Zakar, V., forthcoming, Kontrastivna analiza na deminutivno-xipokoristicite, deminutivno-pejorativite, augmentativo-pejorativite $i$ augmentativoxipokoristicite vo makedonskiot i gornolužnihkiot jazik [Contranstive analysis of dimininutive-hypochoristic, diminutive-pejorative, augmentative-pejorative and augmentative-hypochoristic formations in Macedonian and Upper Sorbian] PhD thesis, University of Leipzig.

Zaliznjak, A.A., 2004, Древненовгородский диалект [The Old Novgorod Dialect], Moscow: Jazyki slavjanskoj kultury. 